\title{
ARCHAEOLOGY OF EARLY COLONIAL INTERACTION AT EL CHORRO DE MAÍTA, CUBA. UN NUEVO TEXTO, UNA NUEVA MIRADA
}

\section{Lisette Roura Álvarez ${ }^{1}$}

\section{Reseña de libro}

La ciencia arqueológica tiene grandes deudas con aquella etapa de la historia caribeña y americana caracterizada por la interacción indo-hispánica en sus primeras décadas, es por ello que el volumen Archaeology of Early Colonial Interaction at El Chorro de Maita, Cuba constituye un título de especial relevancia. Las características de este excepcional yacimiento arqueológico, las numerosas interrogantes que aún albergaba y el desarrollo de las técnicas analíticas, suscitaron la revisión de los materiales exhumados y el emplazamiento de nuevas áreas de excavación, dando lugar a una amplia interpretación de la locación que revela su especial significado.

Se trata de una obra del reconocido arqueólogo cubano Roberto Valcárcel Rojas, que vio la luz en el ańo 2016 como parte de la serie Ripley P. Bullen del Museo de Historia Natural de la Florida, y una de las pocas monografías de arqueología de Cuba publicada en inglés.

El libro se sostiene en una compleja investigación que conecta estudios de cultura material, arqueología mortuoria, antropología física y fuentes

1. Lisette Roura Álvarez. Especialista en Arqueología Histórica en el Gabinete de Arqueología de la Oficina del Historiador de la Ciudad de la Habana. E-mail.roura@patrimonio.ohc.cu históricas. Se apoya en una extensa bibliografía, indispensable para la exitosa realización de una investigación de tal envergadura, combinando fuentes de información de diversas épocas, incluyendo diversos registros documentales. Ampliamente ilustrada, ofrece imágenes de gran calidad y desde los requerimientos del texto y sus argumentos, entre las que se destacan un amplio anexo sobre cerámicas coloniales.

La organización y concordancia de temas se ajustan al propósito del investigador, aportando un discurso intenso y bien fundamentado, antecedido por un excelente prefacio que capta exitosamente la esencia e implicaciones de la publicación y las intenciones del autor. El prefacio fue preparado por William F. Keegan, curador de Arqueología en el Florida Museum of Natural History y responsable de la traducción al inglés, tarea compleja que, en este caso, abre oportunidades para el conocimiento de la arqueología cubana en el entorno académico anglosajón.

La interpretación de los resultados investigativos del sitio El Chorro de Maíta y su relación con los datos de otros yacimientos estudiados ofrecen nuevas perspectivas que permiten analizar la interacción indo-hispánica a nivel regional, aspecto poco logrado en Cuba y en las Antillas en general. Asimismo analiza los diferentes grados y tipos de la 
misma mediante su reflejo a nivel artefactual, ya que cada producto es una manifestación diversa, según las condiciones materiales y la situación histórica particular, con diferentes niveles de objetivación. Identificar arqueológicamente la situación de contacto y la situación colonial permitirá esclarecer las coincidencias crono-espaciales de grupos culturales diferentes en determinados territorios, y proponer modelos específicos de análisis e interpretación.

El sitio se revela como un singular espacio marcado por las circunstancias del sistema de encomienda, el primero de su tipo identificado en el Caribe, donde la vida y la muerte muestran los ajustes, persistencias y cambios de actores étnica, social y culturalmente diversos. Indígenas encomendados y esclavos, un africano y posibles mestizos, reposan en un cementerio de concepción cristiana emplazado en una aldea de origen precolonial. Es un escenario de dominación hispana donde se transforman las identidades y donde también se persiste, descalificando el discurso de colapso, e incapacidad de resistencia indígena. Esta visión cambia los presupuestos tradicionales sobre el lugar, insistiendo en su faceta colonial.

El texto resume un estudio de varios años, Premio Nacional de la Academia de Ciencias de Cuba, que involucró especialistas e instituciones de la Isla y diversas partes del mundo. Nos deja un ejemplo de cómo conectar múltiples técnicas de investigación y reevaluar estudios previos para potenciar sus datos, creando el tan necesario puente entre arqueología precolombina e histórica, al enfrentar el reto de reconocer un momento clave de nuestra historia.

El Dr. Roberto Valcárcel nos propone nueve capítulos de una lectura amena, aguda e inspiradora, excelentemente estructurada y dinámica, combinando teoría y análisis artefactual magistralmente. La integralidad cualifica este título y pone de manifiesto la sistematización en las labores arqueológicas efectuadas. La selección y aplicación de un acertado y novedoso aparato conceptual nos revela la necesidad de actualizar los presupuestos teóricos utilizados tradicionalmente como arquetipos de la investigación arqueológica, por lo que constituye un libro que con una mirada renovadora y fresca nos convoca a la reflexión sobre resultados de estudios precedentes. Si estos fueran los propósitos del autor, me atrevería a asegurar que fueron plenamente alcanzados.

University Press of Florida ha tenido el atino de publicar esta obra, que sin dudas puede considerarse una de las más novedosas contribuciones a la arqueología caribeña.

\section{Referencias}

Valcárcel Rojas, R. (2016). Archaeology of Early Colonial Interaction at El Chorro de Maita, Cuba (W. F. Keegan, Traducción y prefacio). Gainesville: University Press of Florida. Florida Museum of Natural History: Ripley P. Bullen Series. 398 páginas, 88 figuras, 30 tablas. http://upf.com/book. asp?id=VALCA00 1

\section{Datos de filiación}

Lisette Roura Álvarez. Es licenciada en Estudios Socioculturales, y actualmente estudiante de doctorado en Ciencias Históricas. Se desempeńa como Especialista en Arqueología Histórica en el Gabinete de Arqueología de la Oficina del Historiador de la Ciudad de la Habana, y sus líneas de investigación principales giran en torno a temas de arqueología industrial; interacción indohispánica, y legado cultural indígena.

E-mail. roura@patrimonio.ohc.cu 